\title{
Between Legal Certainty and Doubt
}

\author{
The Developments in the Procedure to Overturn Wrongful Convictions in the Netherlands
}

\author{
Nina Holvast, Joost Nan \& Sjarai Lestrade*
}

\begin{abstract}
The Dutch legislature has recently (2012) altered the legislation for post-conviction revision of criminal cases. The legislature aimed to improve the balance between the competing interests of individual justice and the finality of verdicts, by making post-conviction revision more accessible. In this article we describe the current legal framework for revising cases. We also study how the revision procedure functions in practice, by looking at the types and numbers of (successful) requests for further investigations and applications for revision. We observe three challenges in finding the right balance in the revision process in the Netherlands. These challenges concern: 1) the scope of the novum criterion (which is strict), 2) the appropriate role of an advisory committee (the ACAS) in revision cases (functioning too much as a pre-filter for the Supreme Court) and, 3) the difficulties that arise due to requiring a defence council when requesting a revision (e.g., financial burdens).
\end{abstract}

Keywords: revision law, post-conviction review, wrongful convictions, miscarriages of justice, criminal law, empirical research

\section{Introduction}

While all legal systems aim to exclude the possibility of wrongful convictions, the reality is that wrongful convictions cannot completely be ruled out. This is also true for the Netherlands. Nevertheless, the legislation in the Netherlands to reopen closed cases for revision traditionally has been restrictive. ${ }^{1}$ In the legislative process, the importance of the principle of finality of legal procedures was of primary importance. ${ }^{2}$ The prevailing idea has been that revision of unjust cases should be possible. However, having a revision procedure should not feed the idea that the normal procedures are inade-

* Nina Holvast is Assistant Professor at the Erasmus Universiteit Rotterdam. Joost Nan is Associate Professor at the Erasmus University Rotterdam. Sjarai Lestrade is Assistant Professor at the Radboud University Nijmegen.

1. Several terms are used to describe the remedy of overturning a final criminal conviction (or, more broadly, criminal verdict), such as (extraordinary) review or revision. In this article, we will use the term revision.

2. See for the legal history J.S. Nan, 'Herziening ten voordele van de gewezen verdachte als buitengewoon rechtsmiddel', 1 Nederlands Tijdschrift voor Strafrecht 11 (2020). quate to provide adequate legal protection. ${ }^{3}$ The legal system requires there to be no subsequent debate on the outcome, unless there are strong and fresh leads indicating that there is something fundamentally wrong with the conviction.

This understanding of post-conviction revision law was jeopardised when various controversial 'wrongful conviction' cases emerged at the beginning of this century (details of these cases are provided in Section 2). After an extensive discussion in parliament, new legislation was passed by means of the Reform of Revision in Favour of Former Suspects Act in 2012. Since 1 October 2013, revising cases to the detriment of former suspects has also been made possible,${ }^{4}$ but that will not be discussed in this article (only one such case has been submitted to the Supreme Court, as of the writing of this article). ${ }^{5}$ The new legislation (described in detail in Section 3) aimed to create a better balance between legal protection against wrongful convictions and the notion of legal certainty by having a legal process that has an end. Improving this balance was expected to be beneficial to the overall trust in the justice system. ${ }^{6}$ In this article we will investigate how the Netherlands currently stands with regard to this balance. Does the new legislation indeed provide a better balance between these principles? And what challenges are still faced in achieving the right balance?

To answer these questions, we use the data from an evaluation study we performed five years after the legislation was passed, which was commissioned by the Ministry of Justice and Safety. ${ }^{7}$ We analysed all the submitted requests for revision and all applications for further investigation (a new opportunity created by the legislation), made in the period October 2012 to December 2017. We also interviewed twenty-eight professionals involved in the revision process and held a meeting with seven experts to discuss our findings. For this article, we also include new developments that have occurred over the years 2018 and 2019. We analysed all deci-

3. See the introduction of legislation in 1899 Kamerstukken I 1898/1899, 78, no. 78; See the recent changes in legislation Kamerstukken II 2008/09, 32045, no. 3, at 5 .

4. See Art. $482 \mathrm{a}$ et seq CCP.

5. Dutch Supreme Court, 8 November 2016, ECLI:NL:HR:2016:2520, NJ 2017, 69, m.nt. T. Kooijmans (Vivaldi). The Supreme Court rejected the petition.

6. Kamerstukken // 2008/09, 32045, no. 3, at 5 .

7. J.S. Nan, N.L. Holvast, S.M.A. Lestrade, P.A.M. Mevis \& P. Mascini, Victa vincit veritas? Evaluatie Wet hervorming herziening ten voordele WODC (2018). 
sions on applications to conduct further investigations in 2018 and 2019, as well as several significant requests for revision.

In Section 2, we start by providing background information on the developments that resulted in the changes in the revision legislation. In Section 3, we describe the new legislation (i.e., the current legal framework in the Netherlands) for post-conviction revision. Section 4 provides an overview of how different parts of the revision legislation (the applications for further investigation and the requests for revision) function in practice. In Section 5, we discuss three challenges for the execution of revision law. In the final section, we conclude that the new legislation results in a marginally better balance and that there remain important attention points regarding post-conviction revision.

\section{Developments that Resulted in Changing the Legislation}

The extraordinary remedy of revision in favour of former suspects (herziening ten voordele van een gemezen verdachte) originated in 1899, after a highly controversial case in which three brothers were convicted unjustly. The three brothers Hoogerhuis were deemed troublesome by the authorities and were wrongfully accused of a robbery, committed in early December 1895. The victims altered their earlier statements, possibly because the District Attorney's office put pressure on them. Only after a famous Member of Parliament, the socialist Troelstra, advocated on their behalf, the conviction of the brothers Hoogerhuis was revised. In the new legislation several rudimentary grounds for revision (such as the fact that the victim of manslaughter turned out to be alive), were reformulated to two grounds: conflicting convictions or a novum. ${ }^{8}$ When the new Criminal Procedural Code (CCP) was enacted in 1926, the remedy took its current place in the legal framework in Article 457 et seq. In 2003, a third ground was added. Revision was also possible if a judgement by the European Court of Human Rights (ECtHR), in which a violation of the Convention was established, made redress necessary. ${ }^{9}$

Events at the beginning of this century pointed to various shortcomings in the revision process and eventually led to another significant change in the legislation in 2012. These events started with a wrongful conviction in the infamous Schiedam Park Murder, a case concerning the rape and murder of a young girl in 2000 in a park in the city of Schiedam. This case illustrates a clear example of a wrongful conviction. A passer-by, who was a known paedophile, was convicted for the murder, primarily on a (later retracted) confession and some circumstantial evidence. In 2004, a year after the final conviction by the Supreme Court, another person confessed to committing the crime, and new convincing evidence indicated that this man was in fact the real murderer. ${ }^{10}$ As a response to this wrongful conviction, an evaluation committee was established (the Committee Posthumus). This committee wrote a report commissioned by the Procurator General, which resulted in various recommendations to improve the investigation and prosecution of criminal cases.

However, at the turn of the century, more miscarriages of justice emerged, and these cases showed that making improvements to the investigation and prosecution alone was not enough. One of these cases was the Putten Murder Case, committed in 1994. In 1995, two men were convicted for raping and murdering a young woman, even though both of their DNA did not match the DNA of a drop of semen found at the crime scene. They had at one point during police investigations, admitted they committed the crimes, but later retracted this. In 2001 this conviction was finally revised. In this case, an expert report regarding a theory of dragging out semen from earlier sexual intercourse played an important role in the conviction. This theory was needed to explain how semen from a third person was found on the leg of the victim, but the two other men subsequently committed the rape and murder. The expert later retracted his report and the statements he made in court. ${ }^{11}$ The expert was now of the opinion that earlier sexual intercourse could be ruled out. ${ }^{12}$ Another case concerned the murder of an 89-year old woman. Ina Post, the caregiver, was convicted for theft and murder of the woman in 1987. The conviction in this case was also based on confessions of the accused that were later retracted. In the revision that finally occurred in 2010 , it was concluded that the police investigations had from the start focused on proving the guilt of Post, instead of trying to establish the facts. A fourth wrongful conviction case concerns Lucia de Berk. In 2003, a hospital nurse, Lucia de Berk, who worked with sick children, was convicted of multiple murders after she was present during a number of unnatural deaths that were statistically highly unlikely to be coincidental. Expert opinions about the deaths being unnatural were important in convicting De Berk, who always claimed her innocence. She was eventually acquitted in 2010.

Several of these cases concerned acquittals that had occurred ten (Putten Murder Case) or twenty (the case of Ina Post) years after the conviction. Evaluations of these

10. This man's DNA matched various crucial samples found at the crime scene, and he possessed knowledge that only someone who was highly involved could know. For an English analysis of this case, see P.J. van Koppen, 'Miscarriages of Justice in Inquisitorial and Accusatorial Legal Systems', 7 Journal of the Institute of Justice and International Studies (2007).

11. This was presumably because he was not aware of the fact that the semen was found on more places on the body of the victim. He now also stated that semen could only be found outside the body within half an hour after intercourse.

12. It was also concluded that undue pressure was used in the police interrogations, which resulted in false confessions by the men accused of the murder. Later, the third person identified, whose semen was found, was convicted for the crime. 
wrongful conviction cases pointed to various additional defects in the regular investigation, prosecution and adjudication of criminal cases. ${ }^{13}$ The cases also uncovered the difficulties in reopening legal procedures to reexamine these cases. All cases displayed early signs that the convictions were wrongful. Nonetheless, the process of getting the cases revised was, without exception, lengthy, and in all cases, earlier requests to reopen the cases were rejected. The cases also revealed how difficult it was for the convicted persons to collect new and convincing evidence to prove their innocence. This resulted in the awareness that existing revision procedures did not provide adequate protection to overcome wrongful convictions. As a result, several measures were taken to improve the existing possibilities to request revision. These measures had two primary aims: 1) improving the possibility of collecting evidence to successfully request a revision, and 2) extending the legal grounds for revisions.

The first measure was taken in 2006 on an ad hoc basis. By means of an experiment, a temporary commission, the Commission Evaluation Closed Cases (Commissie Evaluatie Afgesloten Strafzaken, CEAS) was formed. ${ }^{14}$ This committee consisted of legal academics, attorneys, police officers and prosecutors. Scientists, or whistleblowers from the prosecution office or police, could submit applications to this committee to conduct research to find defects in the investigation of cases. The core purpose of the commission's work was evaluative, yet in practice, the reports exposed essential information that was used to substantiate requests for revision at the Supreme Court.

The CAES was however a temporary solution. Furthermore, the CAES's goal to evaluate the investigation process made it unsuitable to provide all relevant material that was legally required for the revision of cases. Establishing the CAES also did not solve the problem that certain new evidence simply did not fit into the legal requirements for revision, even though many legal experts agreed that such evidence should provide a reason to consider revision. In particular, new expert evidence did not fit the legal requirements for revision. These shortcomings resulted in two key alterations to the existing legal framework: the creation of a new procedure that (in serious cases, prior to an application for revision) provides former suspects the opportunity to request that the Procurator General initiates further investigations into the existence of new evidence, and the amendment of the novum criterion to encompass more situations. The new opportunity to request further investigations also resulted in the establishment of a new advisory committee to examine these cases, called the ACAS (Advies Commissie Afgesloten Strafzaken, or the Advisory Committee for Concluded Criminal Cases).

13. See CEAS-reports on the Enschedese ontuchtzaak, Lucia de B. and Ina Post.

14. See more about this committee in J. de Ridder, C.M. Klein Haarhuis \& W.M. de Jongste, De CEAS aan het werk. Bevindingen over het functioneren van de Commissie Evaluatie Afgesloten Strafzaken WODC (2006-2008)

\section{Legal Framework for Revision}

In this section, we describe the grounds for revision, the legal framework to request further investigations and the legal requirements of the procedure to apply for revision.

\subsection{Grounds for Revision}

\subsubsection{Conflicting Convictions}

There are three grounds for revision. The first ground for revision under Article 457, paragraph 1 CCP (sub a) is the circumstance of conflicting convictions. This circumstance rarely occurs. The conflict needs to consist of factual findings concerning the perpetration of the crime or crimes. At least one final conviction and another conviction in which the proved charges in both cases are incompatible with each other are required. Both judgements have to have been given by a Dutch criminal court. Two types of conflicts are possible. First, the conflict can involve the same convicted person. For instance, someone may be convicted of theft at a given time and place but, according to another verdict, was at the other side of the country at that specific time, committing another crime. Second, a conflict can also occur if different persons are involved and there are judgements stating that they both committed the same crime (not in any sort of collaboration). In both situations, the convictions are contradictory, and at least one of them is wrong.

\subsubsection{A fudgement by the ECtHR}

The second ground for revision is a judgement of the ECtHR in which a breach of the Convention or any of the protocols of the ECHR is established and revision is necessary to redress the breach (as mentioned in Art. 41 ECHR sub b). ${ }^{15}$ This ground was established in $2003^{16}$ and is limited to judgements of the ECtHR only; verdicts of other international tribunals such as the United Nations Human Rights Committee in Geneva or the EU Court in Luxembourg are not included. A unilateral

15. See P.H.P.H.M.C. van Kempen, Heropening van procedures na veroordelingen van het EHRM. Over redres van schendingen van het EVRM in afgesloten strafzaken alsook afgesloten civiele en bestuurszaken (diss. Tilburg) (2003). According to the ECtHR, the reopening of proceedings or a retrial could be an appropriate way to redress a violation, but this is not always mandatory, Moreira Ferreira v. Portugal no. 2, ECHR (2017) App. No. 19867/12, 47-51, NJ 2019, 280, m.nt. P.A.M. Mevis.

16. The attempt of Van Mechelen to have his case revised after a successful complaint in Strasbourg on Art. 6 ECHR (the right to interrogate anonymous witnesses (police officers)), failed in 1999. The ECtHR judgement was not considered a novum, and the law did not offer revision on another ground. The Supreme Court did not see it as its role to overcome this legal gap. Therefore, the legislature acted. See Van Mechelen and Others v. The Netherlands, ECHR (1997) App. No(s). 21363/93, 21364/93, 21427/93 and 22056/93; Dutch Supreme Court 6 July 1999, ECLI:NL:HR:1999:ZD1603, NJ 1999, 800, m.nt. J. de Hullu (Herziening na Straatsburg). The same goes for a ruling by the EU court in Luxembourg, Dutch Supreme Court 9 April 2019, ECLI:NL:HR: 2019:546, NJ 2019, 439, m.nt. P.A.M. Mevis. 
declaration of the Dutch government that the ECHR or a protocol has been breached does not appear to be sufficient. ${ }^{17}$ There have been only a few examples of successful pleas for revision on this ground, such as the Vidgen case and the Hokkeling case. ${ }^{18}$

\subsubsection{Novum}

The third, and most commonly used, ground for revision is a novum (sub c). Under the current legislation, a novum requires that there is 'a data point' (een gegeven). ${ }^{19}$ This data point should have been unknown to the court during the court hearing. Furthermore, it should either on its own or in relation to the previously submitted evidence seem incompatible with the judgement, to such an extent that a serious suspicion arises that, should this data point have been known, the investigation into the case would have resulted in the former suspect being acquitted or discharged from prosecution, in the prosecution being barred or in the application of a less penal provision. Before the new legislation was enacted in 2012, instead of a 'data point', the legislation referred to 'a circumstance'. This circumstance had to be new and important and it had to be of a factual nature. Because in some cases this concept was considered too narrow, the Supreme Court on occasions made an exception to the requirement that the new evidence was of a factual nature and broadened its scope. New forensic expertise was, in special circumstances, also framed as a novum. ${ }^{20} \mathrm{~A}$ good example is the aforementioned Putten Murder Case, in which the expert was of a different opinion at a later stage, based on facts which were new to him. In the case of Lucia de B. the conviction was also revised due to a new expert opinion. This opinion was based on more medical data than the previous expert had available, now indicating a natural death of one of the children. The change in the legislation was specifically aimed to avoid the necessity of such figurative constructions of the Supreme Court. ${ }^{21}$ One could argue that the stipulation itself was significantly changed (extended) but that the actual impact was limit-

17. See, for example, the Keskin case, Keskin v. The Netherlands, ECHR (2015) App. No. 2205/16 (communicated case).

18. Vidgen v. The Netherlands, ECHR (2012) App. No. 29353/06; Dutch Supreme Court 4 June 2013, ECLI:NL:HR:2013:CA1782, NJ 2013, 333; Dutch Supreme Court 6 June 2017, ECLI:NL:HR:2017:1017, NJ 2017, 378, m.nt. J.M. Reijntjes (Post-Vidgen); Vidgen v. The Netherlands, ECHR (2019) App. No. 68328/17. Hokkeling v. The Netherlands, ECHR (2017) App. No. 30749/12; Dutch Supreme Court 19 September 2017, ECLI:NL:HR:2017:2412, NJ 2019, 281, m.nt. P.A.M. Mevis. Since 2012, co-conspirators of the applicant can also benefit from a judgement by the ECtHR, depending on the nature of the breach.

19. A data point could be a new piece of 'hard' evidence such as a statement by a witness, a fingerprint or DNA trace, but also a (revised) opinion of an expert.

20. See Dutch Supreme Court 26 June 2001, ECLI:NL:HR:2001:AA9800, N 2001, 564, m.nt. T.M. Schalken (Putten Murder Case) and Dutch Supreme Court 7 October 2008, ECLI:NL:HR:2008:BG1941, NJ 2009, 44, m.nt. P.A.M. Mevis (Lucia de B. Murder Case). For an analysis (in Dutch) of the qualification as nova in the Ina Post and the Deventer Murder case see H.F.M. Crombag, H. Israëls, P.J. van Koppen \& W.A. Wagenaar, 'Twee nova: Ina Post en de Deventer moord-zaak', 8 Nederlands Juristenblad 378, at 475-478 (2010)

21. For the parliamentary history, see Kamerstukken II 2008/09, 32045, no. 3, at 9-11 and 27. ed since it mainly encompassed a codification of the exceptions the Supreme Court already made. There is an ongoing (parliamentary) debate on whether the 'serious suspicion' requirement should be lowered to further extend this ground, and whether, for instance 'reasonable doubt' would suffice to have a case retried (see also Section 5). ${ }^{22}$

In the interpretation of what constitutes a data point, expert evidence was particularly central to the discussion. On the basis of parliamentary history, there are four new situations in which new expert evidence could provide a data point. ${ }^{23}$ In an important ruling, the Supreme Court set out some principles on this topic. ${ }^{24}$ Hereby, an explicit reference was made to the legislative history for cases in which an expert opinion can provide new evidence. ${ }^{25}$ The Supreme Court imposed specific requirements on experts ${ }^{26}$ and their opinions. Any expert opinion/insight which is presented as new and/or revised must be of sufficient quality and weight to lead to a revision of the judgement, and the revision application must provide sufficient clarity such that the content and novelty of this opinion can be deemed of value. The mere fact that an expert has a different view on the evidence does not give rise to the mandatory 'serious suspicion'. Changes in law, in case law or in the public view on the criminality of the proved conduct are not a data point, nor is a verdict from the EU Court in Luxembourg. ${ }^{27}$

\subsection{A Further Investigation}

Under the new provisions enacted through the Reform of Revision in Favour of Former Suspects Act, former suspects may turn to the Procurator General and request that a further investigation is initiated in preparation of a revision application' (Art. 461, paragraph 1 CCP). This relates to a situation in which reasonable doubt exists about the correctness of a judgement, but without further investigation there is insufficient information to

22. See Nan, above n. 2.

23. These are, first, the situation in which the relevant question, which is directly related to proven charges, has not yet been submitted to an expert. Second, there is the situation that a new expert, from another field of expertise or on the grounds of other investigative methods, arrives at new conclusions. Third, there is the case that, on the grounds of the same facts, a new expert reaches another opinion because the previous expert opinion was based on incorrect factual assumptions or because there are new developments in the relevant field of expertise. Fourth, there is the situation that the expert backtracks from his or her original opinion because this opinion was based on an incorrect premise due to the lack of correct initial information.

24. Dutch Supreme Court 17 April 2018, ECLI:NL:HR:2018:605, NJ 2018, 272. See also Dutch Supreme Court 26 April 2016, ECLI:NL:HR: 2016:736, NJ 2016, 305, m.nt. J.M. Reijntjes.

25. The ruling did not specifically refer to the fourth situation (the expert backtracks from his or her original opinion because this opinion was based on an incorrect premise due to the lack of correct initial information).

26. One factor is whether the expert is officially registered as an expert (in the Nederlands Register Gerechtelijk Deskundigen).

27. Dutch Supreme Court 12 March 2013, ECLI:NL:HR:2013:BZ3627, NJ 2013, 438, m.nt. N. Keijzer (Tongzoen II); Dutch Supreme Court 25 June 2013, ECLI:NL:HR:2013:73, NJ 2013, 548, m.nt. T.M. Schalken and Dutch Supreme Court 9 April 2019, ECLI:NL:HR:2019:546, NJ 2019, 439, m.nt. P.A.M. Mevis. 
build a revision application. The legislature is aimed at creating a new opportunity to mitigate a former suspect's weak position in providing evidence of a wrongful conviction.

Investigations can only be requested when they are expected to result in a novum. The request to have further investigation into new evidence cannot be submitted for every conviction, only for more serious offences. A request should concern a criminal offence that is subject to a prison sentence of a minimum of twelve years. Cumulatively, it is also required that the criminal offence in question has 'seriously shocked' the legal order. The Procurator General may only reject the request if there are insufficient indications of potential new evidence or if the requested investigation is unnecessary. $^{28}$

On the grounds of Article 462, paragraph 1 CCP, the Procurator General may, on his or her own initiative, or at the request of the former suspect, decide in advance to submit a request to 'a committee charged with advising on the desirability of a further investigation'. As mentioned before, this independent and impartial committee is called the ACAS. ${ }^{29}$ Just like its predecessor (the CEAS), members of the ACAS are not necessarily lawyers. The ACAS consists of academics, attorneys, (former) police officers and prosecutors. In cases in which a prison sentence of six or more years has been imposed (which is true for most cases), it is compulsory for the Procurator General to obtain advice from the ACAS. It is not compulsory for the Procurator General to obtain advice when he or she decides that the request could be upheld, or declares the request inadmissible or manifestly ill-founded. The ACAS has the task 'of advising the Procurator General on the desirability of a further investigation' as referred to in Article 461, paragraph 1 CCP. ${ }^{30}$ During its assessment, the ACAS can conduct some modest investigation itself, such as interviewing experts and persons involved in the original investigation. The Procurator General initiates these further investigations, if he or she upholds the request. ${ }^{31}$ Further investigation is not unlimited. The Procurator General can designate a specific investigation to a court's investigating judge, who was not previously involved in the case. In addition, the Procurator General may be assisted by an investigation team. During further investigation, if needed, digital and physical evidence can be seized, DNA can be tested and witnesses and experts can be interviewed.

28. In cases that do not meet these requirements, a further investigation is possible after a petition to revise the case is filed; see Arts. 465,468 and 469 CCP.

29. Established by the Advisory Committee for Concluded Criminal Cases Decree.

30. Art. 462, para. 1 CCP, and Art. 2 of the Advisory Committee for Concluded Criminal Cases Decree and Art. 2.1 of the Internal Rules of the Advisory Committee for concluded criminal cases. The ACAS should deal with the task in an impartial and independent way, whereby it can decide its own way of working (as well as its internal rules).

31. See Arts. 463-4 CCP. The Procurator General can also start a further investigation without a request by the former suspect, even though this is not written down in the law itself.

\subsection{Procedure}

Only a verdict of a Dutch criminal court that is final can be subject to revision. ${ }^{32}$ The former suspect can request the revision but needs formal representation (the requirement of formal representation was introduced in 2012). The request needs to state the grounds on which it is based, the relevant documents that can sustain the request and a copy of the verdict holding the conviction that needs to be reviewed. After the death of a former suspect, certain family members are eligible to submit a request for revision. The Procurator General can also file a petition for revision and has done so on some occasions. ${ }^{33}$ The Supreme Court handles the request, which has to be in writing. There is no time limit after the final verdict for submitting a request and no limit to the number of requests that one can submit. ${ }^{34}$ The fact that the Procurator General, next to (the family of) the former suspect, has the independent authority to request revision, indicates that revising criminal convictions is not only in the interest of a former suspect (and his legacy), but also in public interest. If the request for revision does not meet the formal requirements, the Supreme Court declares it inadmissible. If it is manifestly illfounded, it is rejected. ${ }^{35}$

If the submission is well-founded, the revision process goes into a second phase. ${ }^{36}$ The Procurator General then gives his or her advisory opinion on the case. In preparation for giving this opinion, the Procurator General can conduct a further investigation or seek advice from the ACAS. The advice of the ACAS is usually given in thorough and detailed reports. In practice, these reports are an authoritative source of information for the Procurator General, as well as the Supreme Court. Legal counsel is offered the option to respond to the advisory opinion of the Procurator General within two weeks. The Supreme Court can order a further investigation by the Procurator General or order the Procurator General to request advice from the ACAS. The Supreme Court can also order one of its own judges, or a fresh investigating judge, to conduct a further investigation. This is highly unusual, but it has occurred (e.g., in the Putten Murder Case, a member of the Supreme Court interrogated the expert). When the Supreme Court possesses of all the information it requires, it passes judgement regarding the revision.

When the Supreme Court rules that there is no ground for a revision, it rejects the request (Art. 470 CCP). If

32. Art. 457, paras. 1 and 2 CCP. In general, courts have limited leeway to address small and obvious errors in their verdicts. If illegal proceeds of crime are taken, and it turns out the sum of the proceeds is actually lower than calculated, a ruling can be given to lower the amount (Art. 6:6:26 CCP)

33. Dutch Supreme Court 19 December 2017, ECLI:NL:HR:2017:3189, N 2018, 251, m.nt. J.M. Reijntjes (Zes van Breda).

34. Expect for cases in which a breach of the ECtHR or any of the protocols is established, revision is necessary for redress, as mentioned in Art. 41 ECHR. Then, a petition needs to be submitted within three months after it can be established that the former suspect knew about the judgement (Art. 465 , para. 2 CCP).

35. Art. 465 CCP. If needed, a further investigation can take place or advice from the ACAS can be asked for.

36. Art. 466 et seq 


\begin{tabular}{llllllllll}
\hline & $\begin{array}{l}2012 \\
\text { (from } \\
\text { Oct.) }\end{array}$ & 2013 & 2014 & 2015 & 2016 & 2017 & 2018 & 2019 & Total \\
& & 10 & 10 & $8^{*}$ & 9 & 3 & 2 & 0 & 44 \\
\hline $\begin{array}{l}\text { Applications for fur- } \\
\text { ther investigation to }\end{array}$ & 2 & & & & & & & & \\
$\begin{array}{l}\text { Procurator General } \\
\text { Of those, applications } \\
\text { submitted to the ACAS }\end{array}$ & 2 & 9 & 10 & 6 & 7 & 2 & 2 & 0 & 38 \\
\hline
\end{tabular}

* Two of these applications concerned suspects in a case in which an application was already submitted in 2014.

there is a ground for revising the conviction, the outcome depends on the legal ground. If a conflict of convictions occurs, both verdicts are annulled, and an appellate court that was not involved in the earlier convictions will handle both cases (see Art. $471 \mathrm{CCP}$ ). ${ }^{37}$ This is because at least one of the verdicts cannot be correct. The reopening of the case because of a verdict by the ECtHR needs to be the appropriate form of redress as mentioned in Article 41 ECHR. This will most likely happen when Article 6 ECHR has been breached according to the ECtHR. ${ }^{38}$ In case of a novum, the conviction is redirected to an appellate court that was not involved in the earlier conviction. This court can either uphold the conviction (and the original sentence if one was given) or annul it. If the original conviction is annulled, the appellate court can a) bar the district attorney from prosecuting, b) acquit the suspect, c) discharge the suspect from prosecution or d) convict the suspect with the application of a less penal provision or a lower sentence (Art. 472, paragraph 2 CCP). The CCP contains further stipulations on, among other things, the detainment of the former suspect or the suspect's release, the verdict of the Supreme Court (which has to be reasoned), the procedure of the retrial, ${ }^{39}$ the settlement by the State of the Netherlands of any compensation and costs previously paid by the former suspect to the disadvantaged party and information to victims and their surviving dependants who require such information. ${ }^{40}$
37. A higher sentence than the original is not allowed

38. But if, for instance, Art. 8 ECHR was not respected, this does not mean that the applicant did not have a fair trial ex Art. 6 ECHR. Financial compensation could suffice, and a retrial does not have to take place. The Supreme Court can address this matter in its verdict on the revision procedure (Art. 472, para. $1 \mathrm{CCP}$ ). See, for example, Dutch Supreme Court 27 September 2005, ECLI:NL:HR:2005:AS8858, NJ 2007, 453.

39. The retrial will be conducted mainly according to the rules applying to appeal, with 'fresh' judges (Art. 476 CCP). In no way may the original sentence be exceeded during the retrial; see Art. 478 para. 1 CCP.

40. Art. 473 et seq CCP.

\section{Revision in Practice}

This section provides insight into the way that the current revision system works in practice. We start by describing the data regarding the process of requesting further investigations to prepare for applying for revision and we continue by providing data with respect to the actual revision procedure.

\subsection{Further Investigations}

\subsubsection{Number of Submitted Requests}

Despite concerns of the legislature about a potential growth in requests for further investigation, the numbers of cases in which suspects made use of this opportunity remained modest. Between 2012 and 2019, a total of 44 requests to conduct further investigations were submitted to the Procurator General. The number of requests was, in fact, on average, lower than what was submitted to the impermanent commission, the CEAS, that existed prior to the change in legislation. This is unexpected, as with the establishment of the new legislation the legislature intended to extend the possibilities to apply for further investigations. However, while on the one hand applying is easier as a former suspect (as the application does not have to be motivated by a scientist or whistle-blower), the need for formal representation may have made applying more difficult; see also Section 5 sub c.

Table 1 shows the number of applications to the Procurator General, as well as the number of applications that were subsequently submitted to the ACAS. Most of the applications were submitted in the first years (2013-2016) after the legislation took effect. Since 2017, only five new applications were submitted in three years. The table shows that most applications were also submitted to the ACAS. This is partly due to the fact that most applications fall under the six-year imprisonment criterion (see Section 3.2). However, also in cases that did not meet this criterion, the Procurator General usually involved the ACAS.

The majority of requests concern homicide cases; a minority are related to assaults, arson and drug traffick- 
Table 2 Decisions and advice to conduct further investigations

\begin{tabular}{|c|c|c|c|c|c|c|c|c|c|}
\hline & $\begin{array}{l}2012 \\
\text { (from } \\
\text { Oct.) }\end{array}$ & 2013 & 2014 & 2015 & 2016 & 2017 & 2018 & 2019 & Total \\
\hline \multicolumn{10}{|l|}{ ACAS } \\
\hline ACAS reports & - & 5 & 12 & 5 & 4 & 6 & 5 & 1 & 38 \\
\hline $\begin{array}{l}\text { ACAS advises to con- } \\
\text { duct further investiga- } \\
\text { tion }\end{array}$ & - & - & 3 & - & - & - & 4 & 1 & 8 \\
\hline \multicolumn{10}{|l|}{$\begin{array}{l}\text { Procurator General } \\
\text { (PG) }\end{array}$} \\
\hline Final decisions by PG* & - & 1 & 10 & 12 & 2 & 6 & 5 & 3 & $\begin{array}{l}39(+1 \\
\text { pending) }\end{array}$ \\
\hline $\begin{array}{l}\text { Decisions by PG to } \\
\text { conduct further inves- } \\
\text { tigation }\end{array}$ & - & 1 & 2 & 1 & - & - & 4 & 1 & 9 \\
\hline
\end{tabular}

* Four requests were not admissible (three in 2015 and one in 2017).

ing. These are all among the most serious crimes, which is due to rules for admissibility (crimes subject to a prison sentence of twelve years and that have seriously shocked the legal order). This limitation is in line with the intention of the legislature to only open this possibility for a limited number of serious crimes, although some have argued for a lower threshold (see Section 5$){ }^{41}$

\subsubsection{Requests that are Granted and Further Investigations Conducted}

While the number of submitted applications is modest, the number of requests that are granted is even more limited. When the new legislation was evaluated in 2018, the ACAS had advised to grant only three of the 28 requests that were submitted to it. The Procurator General has, since the enactment of the new legislation, followed the advice of the ACAS (on main points) in all of the decisions ( 33 cases decided up to and including 2017). Thus, the Procurator General also granted the submission in all three requests. In one additional request, which was not submitted to the ACAS, the Procurator General also granted the permission to conduct further investigations. These numbers can be found in Table 2 (the numbers do not add up to the number of applications because some cases are still pending).

When we conducted our evaluation study in 2018 , several attorneys involved in submitting requests for further investigation mentioned being disillusioned by the number of requests that were denied. They believe that the ACAS and the Procurator General are too strict in granting requests, making it nearly impossible for sus-

41. See Nan et al., above n. 7, at 77 . pects to have further investigations conducted on their cases. ${ }^{42}$ Together with the fact that the process of handling the requests is time-consuming (we found the total duration from application to decision from the Procurator General to be on average one year and three months), this could result in suspects and their attorneys deciding not to bother submitting requests for further investigation. This would be problematic as the purpose of the new legislation - to offer suspects extra support in substantiating their requests for revision would be in danger (see also Section 5.3).

Since the publication of our evaluation study (in 2018 and 2019), the Procurator General published eight new decisions. When these decisions are considered, a somewhat different picture of the success rate emerges. In the first five years and three months (October 2012 to 2017), four of 31 requests for further investigations resulted in a (partly) positive decision by the Procurator General (13\%). In the last two years (2018 and 2019) five of the eight new decisions taken (of which three concern different suspects in the same court case) granted (part of) the request to conduct further investigation $(63 \%)$. This brings the success rate over the total duration of seven years and three months to $23 \%$.

As cited in Section 3.2, the ACAS has the possibility to single-handedly conduct some modest investigations needed to support their advice. The ACAS made use of this in approximately $40 \%$ of its cases. ${ }^{43}$ This means that some form of investigation is taking place more regularly, even when these eventually result in denying a request.

\footnotetext{
42. Ibid., at 68-69; see also G.G.J.A. Knoops, 'Herziening in strafzaken anno 2018: ten voordele of ten nadele?', Nederlands Juristenblad 2018/1646, afl. 31, 2322-2328 (2018).
}

43. ACAS jaarverslag 2017, at 11. 


\begin{tabular}{lll}
\hline & $\begin{array}{l}\text { Revision applications handled by the } \\
\text { Supreme Court }\end{array}$ & Percentage of total \\
\hline Well-founded & 55 & 24 \\
\hline Ill-founded & 131 & 57 \\
\hline Inadmissible & 41 & 18 \\
\hline Partly ill-founded/ partly inadmissible & 4 & 2 \\
\hline Total & 231 & 100
\end{tabular}

Table 4 Applications for revision handled by the Dutch Supreme Court per year

\begin{tabular}{llllllllll}
\hline & $\mathbf{2 0 1 2}$ & $\mathbf{2 0 1 3}$ & $\mathbf{2 0 1 4}$ & $\mathbf{2 0 1 5}$ & $\mathbf{2 0 1 6}$ & $\mathbf{2 0 1 7}$ & $\mathbf{2 0 1 8}$ & $\mathbf{2 0 1 9}$ & Total \\
\hline Revision applications & 27 & 39 & 31 & 33 & 37 & 27 & 18 & 19 & $\mathbf{2 3 1}$ \\
\hline Well-founded & 8 & 7 & 5 & 11 & 13 & 6 & 4 & 1 & 55 \\
\hline III-founded & 13 & 27 & 20 & 15 & 19 & 16 & 9 & 12 & 131 \\
\hline Inadmissible & 6 & 3 & 6 & 6 & 5 & 5 & 5 & 5 & 41 \\
\hline $\begin{array}{l}\text { Partly ill-founded/ } \\
\text { inadmissible }\end{array}$ & 0 & 2 & 0 & 1 & 0 & 0 & 0 & 1 & 4
\end{tabular}

Thus, in recent years, more decisions in favour of conducting further investigations were taken by the Procurator General. The ACAS has also advised positively more frequently. This could indicate a drift towards a more suspect-friendly interpretation of the legal framework for conducting further investigation (see also Section 5.2). However, considering the small numbers, it would be misleading to indicate this as a general trend, as all cases consider unique circumstances. Moreover, the process of deciding on the cases, especially in the more complex cases, has taken several years.

\subsection{Applications for Revision}

In the period from October 2012 to the end of December 2019, 231 revision applications were handled by the Supreme Court. ${ }^{44}$ Those applications related to convictions for 'minor' offences such as light traffic offences and motor insurance problems because of mistaken identity, but also serious offences such as theft, fraud, abuse, human trafficking and murder. Also, a substantial number of the cases (106 in total) are a result of errors in odour tests using sniffer dogs to detect drugs (in which it turned out that the handler of the sniffer dog knew beforehand which one of the vials contained the odour of the suspect, which was not allowed according to the procedural rules).

From October 2012 through December 2017, only seven applications were based on Article 457, paragraph 1
CCP sub a (conflicting convictions in the Netherlands) and sub $b$ (in breach of the ECHR Convention). The other applications were founded on the third ground for revision (Art. 457, paragraph 1 CCP sub c), a supposed novum. In $11 \%$ of those applications, the applicant made use of the new possibilities offered by the broadened concept of the novum (established in the 2012 legislation). The 'nova' that have been brought forward concern, for example, alleged personality changes, new or changed statements from the witnesses or the suspects, new DNA material or other new scientific evidence.

Of the 231 applications dealt with in the period from October 2012 to December 2019, 55 were declared wellfounded, 131 were ill-founded, 41 were declared inadmissible and 4 were declared partly unfounded and partly inadmissible (Table 3).

Compared to the years 2006 to 2011 (before the new legislation), the percentage of applications declared wellfounded has decreased. In the period 2006-2011, 27\% of all applications for revision were declared well-founded, $50 \%$ ill-founded and 23\% inadmissible. However, these figures are somewhat distorted by applications that were a result of errors in odour testing (97 in total), that occurred mainly between 2006 and 2011. ${ }^{45}$ Table 4 shows the number of applications per year since 2012 . 
From October 2012 until the end of December 2019, an average of 32 applications for revision per year were handled by the Supreme Court. This is considerably less than the six years before the legislative amendment. During that period, the number of applications for revision that were processed was more than double, an average of 72 cases per year. Even when the cases concerning errors in odour tests are subtracted, the average number of applications for revision processed per year is still considerably lower than in the six years prior to the amendment of the law. ${ }^{46}$

For our evaluation study, we interviewed different key actors involved in the revision process. They provided various possible explanations for this decrease. Various respondents (from the prosecution office, the police, the judiciary and the ACAS) suggested that the police and the judiciary have learned from previous mistakes that came to light in the wrongful conviction cases that were mentioned in Section 2, and that currently it is less likely for investigative errors to be made. Various measures were introduced after the Schiedam Park Murder to prevent miscarriages of justice. The manner in which interrogations and forensic investigation teams worked in the 1990s differs from how they operate today and police officers are better at reporting their investigative actions. Furthermore, the introduction of peer opposition, reflection and peer supervision should result in more attention for alternative scenarios. Additionally, at times, forensic experts are involved during interrogation and, moreover, attorneys are currently present during the police interrogations. It has also been observed that after the Schiedam Park Murder, relatively more criminal cases ended in acquittals, also for serious cases. ${ }^{47}$ This could be a sign that fewer suspects were wrongfully convicted. However, some interviewed forensic experts were more critical about the supposed progression that was made within the investigative authorities. ${ }^{48}$ These respondents emphasised that wrongful convictions appear at all times. They believe that the number of cases that would qualify for revision is actually much higher, for instance, because former suspects are not able to afford legal counsel. And even if they do, the suspects are often not taken seriously by the legal system, including their defence lawyer.

46. In the years 2006 to 2011 , a total of 97 revision cases were dealt with as a result of these (alleged) mistakes. In the years 2012 to 2019, this number was nine. Excluding the odour test cases, the number of judgements in revision cases from 2012 to 2019 amounts to 222 (an average of 31 cases per year) and for 2006 to 2011, this concerns 333 cases (an average of 56 cases per year).

47. Raad voor de Rechtspraak in Rechtstreeks 2007-3, Strafrechter en strafketen: de gang van de zaken 1995-2006 (www.rechtspraak.nl/ SiteCollectionDocuments/Rechtstreeks-2007-3.pdf) at 34.

48. By forensic experts, we mean legal psychologists, criminologists, forensic trace investigators and legal philosophers.

\section{Challenges in the Revision Process}

The Reform of Revision in Favour of Former Suspects Act therefore provides some new prospects for addressing potential wrongful convictions and substantiating applications for revision with evidence. Nonetheless, the new provisions do not appear to have severely altered the already existing practices of revision. The legislative changes were intended to provide more possibilities to bring forward potential wrongful convictions, but, in fact, fewer applications for revision were submitted along with fewer requests for further investigation. Although it is possible that the applications have simply dropped because improved investigations have resulted in less wrongful convictions, it remains important to guarantee that the revision process is accessible and functioning well. In this context, we observe three key challenges in the current functioning of the Dutch revision law, which relate to: 1) the novum criterion, 2) the role of the ACAS in the revision process and 3) the access to the revision procedure.

\subsection{The Novum Criterion}

Although the legislation concerning the revision procedure in 2012 was amended substantially to extend the possibilities of a successful request for revision, critics pointed out that this primarily concerns a codification of the exceptions to the old criterion that the Supreme Court was already willing to make. ${ }^{49}$ Also, some critics believe the new criterion is still too strict. ${ }^{50}$ Thus, the current legislation did not end the discussion regarding the criterion. On the contrary, an ongoing discussion is taking place on the legal criterion to decide whether something qualifies as a novum. Several defence lawyers, scholars and politicians advocate an extension of the criterion to 'an unsafe conviction' or 'serious or even reasonable doubt on the righteousness of the conviction'. ${ }^{51}$ This was partly based on new cases that were brought forward, in particular the Arnhem Villa Murder case. In this case, the initial conviction of nine men appeared to be wrongful, but it proved difficult to start a revision procedure under the new novum criterion. After the final conviction in this case, the manner in which the police interrogations took place (resulting in incriminating statements of two convicted that were the key evidence in the case), were criticised. The retraction of the statements by one of the convicted was brought forward as a novum. However, the Procurator General has recently advised the Supreme Court to declare the

49. Knoops, above n. 42.

50. See, for example, P.J. Van Koppen and R. Horselenberg, 'Waarom er in België en Nederland geen rechterlijke dwalingen zijn', Expertise \& Recht 278 (2018); A.P.A. Broeders, 'Misleidend bewijs', Expertise \& Recht, afl. 1, 1-3 (2018).

51. See, for this discussion, Nan, above n. 2. See also Knoops, above n. 42. Crombag et al., above n. 20, afl. 8, 475-478. R. Van der Hulle and R. Van der Hulle, 'Herziening en gratie op basis van een nieuwe rechtsopvatting van de rechter: een vergelijking met de Verenigde Staten', RM THEMIS 12-17 (2017/1). 
applications inadmissible, because the Appellate Court had already addressed the credibility of these retracted statements in depth. ${ }^{52}$ An extended criterion would make it easier to overturn this and other potentially wrongful convictions, considering that currently too many cases fall by the wayside. In our evaluation study, certain scientists and attorneys stated that they are in favour of an extended novum criterion. ${ }^{53}$ These respondents pointed to the limited successful revision cases so far and the fact that in all the (eventually successful) revision cases, the convicted faced great difficulties in bringing their cases to the Supreme Court.

Most of the interviewees, however, were wary of such an extension. They were worried that this would open the floodgates to requests for revision. These respondents were also concerned about the principle of finality, as they figured that in a considerable number of cases, there will always remain room for discussion. In their view, a further extension would create problems for the authority of court judgements and for the capacity of the organisations involved and could cause unnecessary unrest (also for victims and their surviving dependants). ${ }^{54}$ There is opposition on extending the criterion for a novum by the legislature too. According to the Secretary of State, extending the criterion would endanger the character of revision as an extraordinary remedy, diminish the faith in the judiciary system if verdicts could be called into question too regularly, stir up the cases with victims, the bereaved and society as a whole and attract too many (of the wrong) cases. ${ }^{55}$ Nonetheless, it is clear that the introduction of a new novum criterion has not ended the discussion regarding the right range of the criterion.

\subsection{The Role of the ACAS}

With the introduction of the possibility to request further investigations and with the establishment of the ACAS, the assembly of persons involved in detecting and overturning wrongful conviction has grown from judges and prosecutors to various other legal experts and researchers. The ACAS has gained a prominent position in the revision process. ${ }^{56}$ In theory, a suspect can directly apply for a revision of his or her case to the Supreme Court. In reality, in the majority of serious cases, the defence lawyer of the suspect first submits a request for further investigation. The reason is that further investigation is usually necessary to substantiate a request for revision in these - often highly complex cases. The increased reliance on expert opinion/insights

52. See ECLI:NL:PHR:66, ECLI:NL:PHR:67, ECLI:NL:PHR:70, ECLI:NL:PHR: 71, ECLI:NL:PHR:72, ECLI:NL:PHR:73, ECLI:NL:PHR:74 and ECLI:NL:PHR:75.

53. One scientist was of the opinion that the question of revision was an empirical question on the guilt of the former suspect and not a legal question.

54. Nan et al., above n. 7, at Sections 4.3 .5 and 6.4.2.

55. Letter Dekker 6 April 2020, Kamerstukken I/ 2019/20, 29279, no. 582.

56. C. Fijnaut and K. Verhesschen, 'Minder juristen, meer andere deskundigen bij de herziening van de herziening in Nederland en België? Een rechtsvergelijkende beschouwing', 6 Expertise en Recht 268-275 (2018). in light of the new novum criterion increases the desirability of having a committee, partly composed of scientific experts, to provide advice on the substantiation of claims in that regard. ${ }^{57} \mathrm{~A}$ defence lawyer we interviewed, who is responsible for a large portion of all applications for revision, also stated that in his or her view, submitting a request for further investigation is simply a step one is supposed to take within the revision process. ${ }^{58}$ The fact that the ACAS is comprised of a varied group of (legal) experts - and thus engages in a more multifaceted analysis of a case - can be a reason for convicted persons and their defence lawyers to include this commission.

In the years since its establishment, the profound and comprehensive reports from the ACAS (including input from various non-lawyers) have been vital sources of information for the Procurator General to make decisions regarding further investigations. While the ACAS reports are often lengthy, the decisions by the Procurator General are commonly short, referring to the data and arguments mentioned by the ACAS.

However, there has been some debate about how to interpret the position of the ACAS in relation to the Supreme Court. The outstanding question is to what extent the ACAS is functioning - and should function as a pre-filter for the Supreme Court, taking the novum criterion as a starting point in advising about requests for further research, or whether the ACAS has a separate responsibility in investigating the reasons for requesting further research and in generating criteria for certain cases that require further investigations. ${ }^{59}$ On the one hand, the ACAS is an independent and impartial committee that is consulted precisely for its broad, and not exclusively legal, expertise. On the other hand, it is pointless to allow further research to be conducted on evidence that will not result in a novum, which is required for revision by the Supreme Court. As clarified in Section 4.1, in the first few years that the ACAS was operating, most of its reports advised negatively regarding the requests for further investigations, and the committee was criticised for acting too much as a pre-filter for the Supreme Court. ${ }^{60}$ Such an image could also negatively affect the willingness of wrongfully accused and their defence lawyers to submit requests for further

57. Ibid., at 272 .

58. Nan et al., above n. 7, at 68. Though, as mentioned, defence lawyers interviewed for the evaluation of the legislation also mentioned being disillusioned by the, in their eyes, strict manner of advising in cases.

59. This dilemma has been mentioned and discussed in various publications; see Den Doelder, 'De ACAS in de Nederlandse herzieningsprocedure', Nederlands Juristenblad (2016/1231); Knoops, above n. 42; C.P.M. Cleiren, 'De ACAS als speler in een gelaagde procedure', Expertise \& Recht (2018), nr. 6, 249, N.L. Holvast, S.M.A. Lestrade \& J.S. Nan, 'De Adviescommissie afgesloten strafzaken; twijfelcommissie of poortwachter van de Hoge Raad?', 6 Expertise en Recht 283-290 (2018). It also continues to be discussed in parliament; see Rondetafelgesprek vaste commissie voor Justitie en Veiligheid 22 mei 2019 over de evaluatie Wet hervorming herziening ten voordele; Kamerstukken II 2019/20, 29279, 543.

60. Nan et al., above n. 7, at 68-69; see also Knoops, above n. 42; Van Koppen and Horselenberg, above n. 50. 
investigations. ${ }^{61}$ More recently, the ACAS has published several reports on cases in which its analysis does not match the characterisation of the ACAS as a pre-filter. In these reports, the ACAS qualifies the convictions as 'potentially unsafe convictions'. This qualification refers to convictions which are 'by current standards incomprehensible decisions by judges regarding the valuation of the facts and the weighing of evidence'. ${ }^{62}$ This description does not fit within the legal description of a novum, because it does not entail a data point unknown to the court. Up to now, the ACAS has qualified five cases (of which three regard three different suspects of the Arnhem Villa Murder case) as 'potentially unsafe convictions' and advised further investigations for that reason. ${ }^{63}$ In none of these cases can a novum, in the sense in which it was meant by the legislature, be easily recognised. Nonetheless, the ACAS advised to conduct further investigations. The Procurator General has followed the advice given by the ACAS for further investigations in all of these cases. None of these cases have thus far been decided by the Supreme Court, as investigations are still pending or have only recently finished. Hence, it continues to be unknown how the Supreme Court will decide in these cases.

\subsection{Effective Access to the Revision Procedure via Legal Representation}

A third significant aspect of the reform of the Revision Act is the introduction of compulsory legal representation. A former suspect can only initiate the revision procedure via a defence counsel. The idea is that a defence counsel is better equipped to put a case forward than a former suspect who is left to use the available legal arrangements on his or her own. At the same time, the belief is that, given compulsory legal representation, the counsel will be able to select cases (early and adequately) and, in doing so, help ensure that the people and resources of the organisations charged with the revision are used efficiently. ${ }^{64}$ However, this compulsory legal representation is also a challenge with regard to effective access to the revision procedure.

Several attorneys indicated that they were hesitant to take on any legal aid revision cases because the remuneration for these cases does not cover their working hours. As a result, compulsory legal representation appears to form a financial threshold for any former suspect with limited means, which was explicitly not the intention of the legislature. If (experienced) attorneys are no longer prepared to take on cases of former suspects with limited means, this jeopardises the access of these convicted persons to the reformed revision provisions. To solve this problem, better compensation could be offered to legal aid lawyers. That way the convicted persons will

61. As was also mentioned by two of the defence lawyers interviewed in our evaluation study; see Nan et al., above n. 7, at 68-59.

62. ACAS jaarverslag 2018, at 13.

63. To wit, ACAS cases no. 22, 26, 28 (Arnhem Villa Murder case), 32 (Rosmalen Flat Murder case) and 37 (Petten Campsite Murder case). See ACAS jaarverslag, 2019, at 10.

64. Kamerstukken I/ 2008/09, 32045, 3, at 33. have access to the revision procedure and to a lawyer to help them adequately present their case.

\section{Conclusion}

The Dutch legislature has recently tried to improve the balance between the competing interests of individual justice and the finality of verdicts, by making the revision procedure more accessible with a reform of the revision legislation (enacted in 2012). In our evaluation study of the reformed legislation (2018), we concluded that, all things considered, a better balance was found. ${ }^{65}$ However, the debate on the adequacy of the possibility of reopening cases post-conviction has not quieted down. There are still several challenges to maintaining and improving the balance. In this regard it is a notable observation that, after a short increase, the new legislation has not resulted in a lot of applications for further investigation or in more requests for revision in recent years. This poses the question of whether the new legislation has changed much in the way that revision cases are dealt with in practice.

We observed three major challenges of the current system. First, the legal criterion to reopen a case on the ground of a novum might still be too strict to overturn verdicts that are simply wrong. The threshold of a new data point that would most likely significantly change the outcome of the case is still too high according to some. The Arnhem Villa Murder case is an example of a case that is difficult to get admitted to the revision procedure, due to the current scope of the novum criterion. Second, while the possibility of re-examining a case before a request for revision is submitted to the Supreme Court is regarded as a welcome instrument to find these much-needed new developments, the outcomes seem somewhat meagre. The ACAS, which provides important advice on the necessity for further investigations, has been criticised of acting too much as a pre-filter for the Supreme Court and thereby being too strict in the advice it gives. The ACAS should, according to some, at this early stage only investigate whether the conviction is safe, without worrying about the legal criterion. In several recent cases, the ACAS has actually done just that and given advice to investigate further (advice that the Procurator General followed). Third, the mandatory legal representation, combined with the limited compensation that attorneys receive for legal aid work, might prove another obstacle for former suspects to have their cases revised, particularly for those with limited means.

It remains to be seen how the Supreme Court will decide in the cases that the ACAS has qualified as 'potentially unsafe convictions' and thus what the criteria for opening closed cases will be in practice. It is furthermore almost inevitable that new cases will present new elements that might stir up debate about new (and

65. Nan et al., above n. 7, at Ch. 6 . 
unforeseen) elements in the revision procedure that may need adjustment, whether just once or on a more permanent basis. For that reason, it is all the more important that convicted persons have effective access to the revision procedure. 